\title{
Public broadcasting crisis as management crisis: a case study of radio television of Vojvodina *
}

\author{
Biljana Ratković Njegovan, Iva Šiđanin ${ }^{* *}$
}

In the context of increasing financial uncertainty for the public service media (PSM) in Serbia, and criticism on its attitudes such as clientelism and political paternalism, the questions of management efficiency of public service broadcasting (PSB) companies and their success in providing quality services are more difficult to answer than ever. The paper analyses the key aspects of the crisis that regional PSB Radio televizija Vojvodine - RTV (Vojvodina Broadcasting Company) has faced since 2005, drawing attention to the lack of strategic performance management over the years. The general framework of the distinguished authors' ideas on the nature and causes of the crisis of European PSBS is provided by comparing those supporting the survival of the PSBs as the "public good" mediating "public values", with the ones criticising severely the "privileged" market position and "continuous state assistance".

Im Kontext der immer größer werdenden finanziellen Unsicherheit für die öffentlich-rechtlichen Medien in Serbien und der Kritik am Klientelismus und an der politischen Bevormundung, ist es heute schwierig über die Fragen bezüglich Effizienz der Verwaltung des öffentlichen Rundfunks und Erfolg bei der Bereitstellung von qualitativ hochwertigen Diensleistungen zu sprechen. Diese Arbeit analysiert die wichtigsten Aspekte der Krise, die der regionale Radiosender televizija Vojvodina - RTV (öffentlich-rechtlicher Rundfunk Vojvodina) seit 2005 durchlebt, und konzentriert sich auf den Mangel an langfristiger strategischer Unternehmensführung. Den allgemeinen Rahmen bilden die Ideen der Autoren über die Art und Ursachen der Krise im europäischen öffentlich-rechtlichen Rundfunk, im Vergleich der Stimmen, die das Überleben des öffentlichrechtlichen Rundfunks als ein "öffentliches Gut", das die "öffentlichen Werte" vermittelt, ünterstützen, mit jenen, die die "privilegierte" Marktposition und "die kontinuierliche staatliche Unterstüzung” kritisieren.

Keywords: Public service media, crisis, media management, Radio televizija Vojvodine, Republic of Serbia (JEL: H12, L82)

\footnotetext{
* Manuscript received: 12.10.12, accepted: 3.12.13 (2 revisions)

** Biljana Ratković Njegovan, Ph.D., Associate Professor, Department of Industrial Engineering and Management, University of Novi Sad, Serbia. Main research interests: Public broadcasting, media management. Email: biljananj@neobee.net

Iva Šiđanin, M.Sc., Teaching Assistant, Department of Industrial Engineering and Management, University of Novi Sad, Serbia. Main research interests: Media management. E-mail: iva.sidjanin@gmail.com
} 


\section{On the crisis of public media organizations}

European PSB companies are large and structurally complex organizations with decades of experience, and approximately all of them went through evolutionary changes - from the stage of monopoly in either market or managed economy, to multichannel, multimedia, convergence and digital switchover (Suter 2005). Public broadcasters are relatively well-resourced and positioned in their target markets, with large audiences and rather firm credibility. However, in the contemporary "new media situation" (Moe/Syvertsen 2007) they have reached "an inflection point" and disrupted traditional balance (BBC 2010) so they should be modernized in many ways not only technologically. Their exceptional institutional history and still defendable political legitimacy can only partly help them justify their economic position, which is regarded as a privilege by the opponents, or assure the public of the importance of social and cultural functions that PSBs perform. Accountability and economic efficiency of PSB companies can only be achieved through socially responsible business strategies stemming from the model of sustainability in dynamically changing societies (Hermida/Ash 2010). But defining this PSB strategy in quickly changing socio-economic environment is unprecedentedly difficult as well; according to Jakubowicz (2006) there is no such strategy, and even if there is, in any of European public media companies, its success is hard to guarantee.

The position of public broadcasting companies in the so called transitional countries is even more complex. Most of them operate on the severely competitive media setting which itself reflects the broader environment, strongly shaped by political clientelism, inadequate regulation, weak institutions and disoriented economy. Hence the crisis of public broadcasting in each particular country experiencing the slow process of transition to market capitalist economy has some specific features, apart from common ones. Over the last two decades public broadcasting organizations in these countries have experienced intense alterations like no PSB in the western European countries have. There was no universally applicable strategy to "copy" or "inherit" for a successful transition of state-owned broadcasting organizations to public service media organizations, just as the country on the whole was unlikely to simply "adopt" the rules and laws (for media policy or cultural policy) of the West European countries.

Consequently, a new type of management in public service organizations was required by inevitable structural changes, redefining business models and strategies (Jakubowicz 2008), organizational adjustments in order to deliver the required level of service. The overall performance of these organizations has been closely related to and hence marked by the type of management as their leading team. Thus, it is up to leaders to articulate new goals and tactics in the rapidly changing environment. 


\section{Criticism and defence of public service broadcasting}

Diversity of PSB models stems from different historical, cultural and political traditions of European nations (Levy 1999, according to Brevini 2010:349). However, in all countries the major centres of political power inclines towards direct control over the largest television and radio stations. Many public service broadcasters in transitional countries in Europe have had to deal with an existential crisis, even in those countries which rapidly advanced in terms of liberal and civilian reconstruction in the 1990s (a striking example is the Hungarian national broadcaster ${ }^{21}$ ). Laws, requests and referrals, both national and European, aimed at reforming public media were sometimes unsuccessful so they are still marked by high level of clientelism and political nepotism (Splichal 2001; BajomiLázár 2002; Hallin/Stylianos 2002; Hallin/Mancini 2004; Jakubowicz/Sükösd 2008).

As pointed out in literature (Owen 1996; Steemers 1999; Picard 2003; Nissen 2006a; Kivikuru 2006; Lowe 2007; Lowe/Bardoel 2007; Car 2007; Jakobowicz 2008) even European public broadcasters with remarkable history have been facing the crisis of identity as well as financial and other problems for years. Their budgets are reduced, public TV channels have lost their priority within younger viewers a long time ago, and their legitimacy has been questioned more frequently than ever before. Even the very idea of the public media is questionable up to the point of considering them to be robust and inefficient, it belongs to the past (Nissen 2006a:2). The choice of media content has become unrestricted and available to almost everyone, so there is no need for public intervention, say the critics (Kivikuru 2006). Besides, PSBs are under attack from their political opponents (Car 2007), on both national and local levels, particularly severe in the form of neo-liberal criticism of public financing, with its "cut, cut, cut!" motto (WTO's is among them labelling the finance of PS TV stations as 'privileged'). There have also been disputes about the types of services they should offer in future, since "broadcasting" was the dominant activity for a long time (Nissen 2006b). There are fears that public broadcasting programmes ought to be marginalized or reduced to "ghettoized" programmes, since neither commercial broadcaster nor wider audience are interested for them (EBU 2009).

However, as the market failures are still present in the digital era, though in different forms, the social importance of public service media still remains. As usually pointed out, the PSB principal functions in that respect are: a) promoting public values; b) protecting media pluralism (The Amsterdam protocol on public service broadcasting 1977); c) fulfilling the social role of improving public wel-

21 Since the 1990s there has been a media war in this country whose turmoil resulted in political hunting, massive lay-offs in public broadcasting, almost legalized persecution of political opponents, interference of government in the selection of independent bodies that control public media. 
fare (McQuail 2003:23), and d) setting standards for media industry (Lowe 2007).

The pros of PSBs are strongly supported by the viewing figures and other audience research results (EBU 2009; EBU-UER 2011). They show that in the majority of countries radio and TV channels of national public broadcasters are most frequently listened to and watched. In spite of dominance of private commercial channels in terms of financial strength and number of channels, public service channels are highly positioned regarding their total viewing/listening time (Nissen 2006a:5; Table 1). Collins et al. (2001) states that PSB should retain its position in the $21^{\text {st }}$ century as well, but the nature of this position will depend on the strategy chosen by PSB itself and the corresponding support from the government. It will also depend on the capacity of public broadcasters to cope with technological changes and the necessity of being competitive and maintain high quality content at the same time.

Table 1: European PSB's market share, all national channels (24h, all audiences)

\begin{tabular}{|l|l|l|l|l|l|l|l|l|l|l|}
\hline & $\mathbf{2 0 0 0}$ & $\mathbf{2 0 0 1}$ & $\mathbf{2 0 0 2}$ & $\mathbf{2 0 0 3}$ & $\mathbf{2 0 0 4}$ & $\mathbf{2 0 0 5}$ & $\mathbf{2 0 0 6}$ & $\mathbf{2 0 0 7}$ & $\mathbf{2 0 0 8}$ & $\mathbf{2 0 0 9}$ \\
\hline Avstia & 55.6 & 54.4 & 53.2 & 50.6 & 50.1 & 47.1 & 46.9 & 42.4 & 41.1 & 38.5 \\
\hline Belgium F1. & 31 & 33.5 & 35.9 & 37.6 & 37.5 & 36.3 & 38.3 & 39.4 & 40.2 & 41.3 \\
\hline Belgivm Fr. & & & & & & & & & & \\
\hline Czech Republic & 31.32 & 29.11 & 29.93 & 29.62 & 30.38 & 29.77 & 31.26 & 31.89 & 31.02 & 28.57 \\
\hline Denmark & 31.8 & 31.0 & 32.0 & 33.6 & 34.0 & 32.7 & 32.5 & 31.1 & 28.8 & 27.0 \\
\hline Estonia & 16.6 & 17.1 & 18.0 & 16.7 & 18.0 & 17.1 & 17.3 & 16.4 & 15.8 & 16.9 \\
\hline Finland & 43.2 & 42.2 & 45.3 & 43.4 & 45.2 & 44.3 & 45.2 & 43.7 & 44.5 & 43.7 \\
\hline France & 40.7 & 40.1 & 39.6 & 39.5 & 38.7 & 37.6 & 37.0 & 35.5 & 34.7 & 32.7 \\
\hline Germany & 43.2 & 43.4 & 44.5 & 44.3 & 45.0 & 44.2 & 45.0 & 43.9 & 44.2 & 43.5 \\
\hline Hungary & 15.2 & 14.8 & 17.1 & 19.1 & 19.1 & 17.6 & 18.6 & 16.6 & 15.0 & 13.6 \\
\hline Ireland & 45.4 & 41.2 & 40.4 & 37.8 & 38.3 & 7.8 & 38.4 & 37.1 & 36.6 & 34.4 \\
\hline Italy & 47.3 & 47.1 & 46.5 & 44.9 & 44.3 & 43.3 & 43.6 & 42.2 & 42.3 & 40.7 \\
\hline Netherlands & 36.6 & 36.1 & 36.1 & 34.4 & 36.1 & 33.2 & 32.8 & 31.3 & 34.9 & 33.9 \\
\hline Poland & 50.6 & 49.2 & 53.0 & 54.5 & 52.2 & 51.2 & 51.1 & 48.3 & 45.5 & 42.2 \\
\hline $\begin{array}{l}\text { Fussian } \\
\text { Federa tion }\end{array}$ & 52.4 & 48.9 & 51.1 & 53.8 & 51.9 & 52.7 & 53.9 & 49.0 & 47.0 & 45.1 \\
\hline Serbia & & & & 26.9 & 28.3 & 28.7 & 34.1 & 33.3 & 33.8 & 31.8 \\
\hline Slovakkia & 25.3 & 27.1 & 25.6 & 24.9 & 29.9 & 25.0 & 24.7 & 22.8 & 22.4 & 20.0 \\
\hline Spain & 32.4 & 32.7 & 32.5 & 30.7 & 28.3 & 25.5 & 23.4 & 22.5 & 22.6 & 22.7 \\
\hline Sweden & 43.2 & 41.9 & 42.9 & 40.5 & 40.4 & 39.7 & 38.3 & 34.5 & 34.1 & 33.1 \\
\hline $\begin{array}{l}\text { Switzerland } \\
\text { German }\end{array}$ & & & 35.9 & 35.4 & 35.2 & 34.1 & 35.3 & 34.2 & 34.8 & 34.0 \\
\hline $\begin{array}{l}\text { Switzerland } \\
\text { French }\end{array}$ & & & 32.6 & 33.1 & 32.3 & 33.5 & 34.1 & 32.2 & 32.0 & 30.7 \\
\hline $\begin{array}{l}\text { Switzerland } \\
\text { Italian }\end{array}$ & & & 32.3 & 35.7 & 37.2 & 36.8 & 35.7 & 34.6 & 35.4 & 33.9 \\
\hline $\begin{array}{l}\text { United } \\
\text { Kingdom }\end{array}$ & & 38.8 & 38.1 & 37.4 & 35.5 & 33.9 & 33.1 & 32.5 & 31.9 & 30.9 \\
\hline
\end{tabular}

Source: EBU / GEAR 2010.

Over the last decade the term surviving has been used surprisingly often in analyses and debates on public service media, which already indicates that these 
are certainly not the times of boundless optimism regarding PSM's financing, organization and management. And yet, valid arguments in favour of good prospects for these media come or can be derived from different standpoints and sources.

Normative institutionalism has articulated the general idea that we live in an uncertain time, a time of bounded rationality (Simon 1957) and bounded cognitive capabilities (Hayek 1945) of individuals and organisations regarding optimal (economic) decision making. Simon (1957) states that such a rationality on both individual and organisational levels stems from, so to say, cognitive-epistemological roots, since rationality requires a full understanding of the situation in which decision making takes place, foreseeing the consequences of particular decision, as well as considering alternative solutions. Since the decision makers rarely have a full knowledge and understanding of the consequences of certain actions (the point of view opposite to the scientific view of management which is based on the rationality of the "homo economicus"), individuals and organisations cannot act as fully rational subjects. Therefore Simon (1957) speaks in favour of institutional viewpoint according to which organisations as formal structures with clearly defined organisational goals and asserted institutional capacity can support the rational decision making and go through (favourable) alternative solutions. This is due to the fact that the performance criteria are defined in advance, and the once established institutional structure of the organisation always tends to protect its developmental path.

That is especially the case in the situation when almost mystical belief in the magic of self-regulating market and "pure" competition declines as the economic-financial crisis deepens. Although economic efficiency is not an inherent characteristic of institutions, they can undoubtedly be of significant help in coping with negative effects of transition.

Public service media comply with the institutional matrix in the sense of North's (1991:97) defining institutions as humanly devised constraints that structure political, economic and social interaction. They consist of both informal constraints (sanctions, taboos, customs, traditions, and codes of conduct), and formal rules (constitutions, laws, property rights). Whilst formal rules can be changed overnight, informal norms provide basic legitimacy and change gradually. Since they comprise set of rules, norms and values, over the course of their almost 90 year old history public PSM have become a remarkable constituent of cultural (ceremonial) heritage. Their communication, social and economic functions have in many ways contributed to social balance, integration processes and stability. Apparently strong tendency towards homogenization in reporting makes the role of national PSBs as political institutions particularly important (Sparrow 1999). 
According to new institutionalists, public service media are in paradoxical situation: they are a type of organization characterized by intensive institutional regulation, but at the same time they operate in a highly competitive environment. With analytical precision Lowe (2007:35) wrote about four paradoxes of public service media: 1) the amalgamation paradox - they are organised and act in the same way as any "norma" business but pursue non-profit public service objectives (all of the "burdens" of business, but none of the benefits); 2) the competition paradox - when PSM is competitively successful it is called market distortion but when PSM is not it is called a waste of public money (damned when they do; damned when they do not); 3) the synergistic paradox - simultaneously achieve centralisation for efficiency and decentralization for effectiveness (be perfectly efficient and perfectly responsive simultaneously); 4) the service paradox - equally emphasize universal service for everybody and personalized services for individuals (facilitate social cohesion and social fragmentation).

Oliver (1991) however sees a possibility of a competitive advantage in such a paradoxical position; that advantage is institutionally built-in on the levels of cognitive, normative and authoritarian capital. Reputation and primary sources of PSBs legitimacy (political consensus is assumed), their long institutional history, formal procedures, firmness, rootedness (Koelble 1995) in social, political and cultural environment (DiMaggio/Powell 1983) should make their further development unquestionable.

Traditional approach of the neoliberal economy is insufficient framework for the neo-institutional narrative in defence of public service media. Their sustainability as non-market institutions (yet a form of capital) with developed organizational structure can be understood in the light of the neo-institutional economy of management, in which not only the exogenous influences of economy and politics, but those of social and cultural factors are considered to be important. The PSM business performance cannot be driven only by the imperative to maximize profits (as the theory of rational choice requires); rules of conduction, norms and roles within their particular institutional structure are important in that respect as well. It is important to decide about possible and acceptable direction for action which, according to Williamson (1991) includes informal and formal rules of "game" - social level (norms, customs, etc.) and the institutional level (political system, laws regulating property, contracts).

\section{Public service media in Serbia}

Serbia was the first country in transition to "open the door" to media pluralism and media market liberalization. In early 1990s these processes were evident in many ways from the rising number of electronic and print media, media ownership liberalization and changes in the ownership structure to even significant liberalization in the editorial policy of a few domestic newspapers (even 3 foreign TV channels entered the Serbian market). That was the decade of an un- 
precedented "explosion" of mostly privately owned electronic and print media, when around 1,500 media (either private or state-owned, in Serbian but also in ethnic minority languages - Hungarian, Slovakian, Romanian, Ukrainian, Macedonian, Roma, Bulgarian, Romanian, Croatian, German) saturated the Serbian market (Milivojević 2006:274). Contrary to such a wave of liberalisation in Serbia, in other countries of the region (Croatia, Bosnia and Herzegovina, FYR Macedonia, Montenegro, Slovenia) the privileged position of the state-owned electronic media and the long-established newspapers was prolonged for a decade (in Croatia, for instance, the first private bidder for a national TV channel concession was Nova TV in 2000).

However, the last decade of the $20^{\text {th }}$ century was marked by a contradictory liberalization: intensive saturation of the media market by a disproportionate mass of radio and TV channels and uncontrolled penetration of numerous privately owned cable networks, as well as control, pressure and direct government influence on the flow of information. By March 2010 there were 886 broadcasting, internet and printed media legally operating in Serbia, and 186 pirate radio/TV channels. Total of 1072 media targeting 7.3 million citizens of Serbia is a true example of highly saturated media market; however, analysts have frequently commented that behind the tzunami of the media offer there was in fact a "multiplication of the same" and "invasion of bad taste" regarding programme content. By the end of 2012 six broadcasting companies obtained valid licences for national TV coverage: RTS (national PSM), TV B92, TV Pink, TV Prva-Fox, TV Avala and Happy TV.

Processes of transformation of national broadcasting organization (RTS) into the Public Service Media of Serbian citizens as well as the Radio Televizija Novi Sad into the regional PSM began in 2005. These two public service companies are independent and differ significantly from one another in the view of management priorities, programme policy and viewing figures. Debates on normative vs. factual functions of public broadcasting began with the Government's decision (2002) to introduce licence fee for funding two public service broadcasters. The intensity and focus of these debates changed over time - starting with the very title (national media service or otherwise) funding sources (licence fee, budget or commercial revenues appropriate), modes of control (parliament, government, independent supervisory bodies) and the manner of appointing representatives in the supervisory bodies. The current situation (2011-2012) is marked by increasingly insecure financing (increasing rate of unemployment, reduced income of the majority of families) and a significant level of even direct impact from the governing political parties. This type of impact is absent in four aspects of the government intervention in the media system about which Blumler and Gurevitch (1995) discussed. The impacts are obvious in terms of media agenda setting, personnel policies, i.e. selection (i.e. appointment) of the senior, 
middle and even junior managers, especially in the media with national coverage, as well as in the local public media (ANEM 2011).

According to a 2007 survey (Strategic Marketing Research 2007), television is the main source of information for $84 \%$ of Serbian viewers. For $37 \%$ of them the national PSB (RTS) ranks first in comparison with the other TV stations (37\%); compared to all the media the RTS enjoyed a 63 percent positive rating. However, the same research showed that the RTS was considered the media with the largest censorship. There are political and corporate pressures on editorial policy since the news programmes offer a privileged treatment to the authorities, particularly national authorities. There is the controlled information about financial wrongdoing of politicians and tycoons, and a tendency of reduction in educational, cultural and artistic content. The national PSB offers more diverse programme than commercial stations.

Radio Television of Vojvodina (RTV) was founded as a public broadcasting institution in 1971. In the period 1992-2005 it had the status of a state broadcasting institution, financed from the state budget, and from 2006 on it is a regional public service broadcaster funded mostly from the licence fee. In organizational terms, it consists of Television Novi Sad One and Two and Radio Novi Sad. With a total of 1,400 employees, RTV broadcasts programme in ten languages (Serbian, Hungarian, Slovak, Romanian, Ukrainian, Romany, Ruthenian, Bunjevac, Croatian, Macedonian) for less than two million inhabitants of Vojvodina. According to the 2011 census, it makes $26.9 \%$ of the total population of Serbia. Unfortunately, the RTV's annual share of audience (Channel 1 plus Channel 2) is below 4\% in the Province of Vojvodina, since its potential audience (around $1,800,000$ individuals aged $4+$ ) watch far more the national PSB channels (RTS1, 2) and the three biggest domestic private channels. Almost 34\% of the RTV1 audiences are the adults over 60 (they make around 23\% of Vojvodina population (2011 Census). On the average, the audience of the Channel 2 (which offers almost all of the programmes in languages of 10 national minorities) is somewhat younger, but not young enough to change the general picture - the RTV has failed to attract young audiences.

Over the period of five years since the RTV enjoys a status of regional PSB no major criticisms of the structure of its programme offering came either from the public or the Programme Council. Yet neither new programme ideas nor improvements in production quality could be seen on the two RTV channels except for a short period $(2007-2008)$ when the (former) management cherished ambition to take advantage of the RTV television portfolio. In 2011 there was a decrease in programme diversity: the $\mathrm{H}^{1}$ index of diversity of programme categories was 0.806 in 2011 as compared to 0.818 in 2009 (Ratković Njegovan/ S̆idanin 2012), which resulted from the increased share of news and current affairs and decreased share of documentaries and children's programmes. Table 2 shows the content structure of RTV 1. 
Table 2: Content structure of RTV 1

\begin{tabular}{lc}
\hline Content structure & Share \% \\
\hline Info & 26.96 \\
News & 10.67 \\
Info + News & 37.62 \\
Entertainment & 18.01 \\
Film & 11.93 \\
Children & 7.43 \\
Documentary & 7.12 \\
TV series & 5.77 \\
Music & 4.06 \\
Scientific and educational & 3.13 \\
Art and culture & 2.23 \\
Religion & 1.42 \\
Sports & 1.28 \\
TOTAL & 100 \\
\hline
\end{tabular}

Source: Republic Broadcasting Agency of Serbia (RBA 2011).

Clearly there could hardly be a well defined and consistent programme policy when four top management teams were appointed (three of them were deposed) between 2005 and 2012, following the political changes in Vojvodina after elections or new coalitions in parliamentary government. Actually none of the four RTV top managements have ever given a clearly defined transparently displayed and publicly discussed program policy document, or development plan, or programming guidelines.

Under the protective umbrella of the political elite who actually made decisions on filling top management positions, the RTV is in certain aspects run more as a 'government-owned corporation' than public media in service of the citizens as "shareholders". An illustration are the "self-dealing" contracts called 'golden parachute' made and signed in 2012 by the top management members (with the exception of the Director General) according to which each of them will receive $€ 20,000$ (i.e. ten exceptionally high monthly salaries) in case of unwilling termination of employment. The information about enormous privileges have only months later leaked since even elementary information on financial performance of the RTV are inaccessible either to the employees or on the RTV's website. Financial crisis (increasingly growing debts since 2009) and unsatisfactory ratings require competent planning of strategic and operative solutions, as well as organizational culture of responsibility, trust and co-operation. Instead, the "hard" pyramidal organization is getting even harder, providing security and power to the top management, in addition to ambiguity of their work.

The results of our survey shed additional light towards the crisis that the RTV calls financial pointing out to the role of management and much more complex crisis behind the financial one. 


\section{Research}

\subsection{Methodology}

\subsubsection{Research problem and objectives}

Our approach to the crisis of public service media was to examine one particular aspect of the PSB crisis - the role that management has or might have in addressing it, as well as in its deepening. The general objective of this exploratory survey was to identify how the role of its management was perceived by the very RTV employees, in relation to three important aspects of the RTV editorial policy: programming criteria, direct political influence and corporate social responsibility. The survey conducted at the RTV in 2011 was the first one to deal with the role of its management.

Ever since its beginnings 38 years ago the RTV as the regional broadcaster has undoubtedly played a substantial role as a multilingual media, cultural and politically influential institution, but always had much safer institutional position than the other ones with these attributes. None of the earlier (rare) criticism or analyses was directed at the organisational/functional aspects of performance of the company which has for years seemed to resist any substantial change, in spite of evidently stagnant quality of programming and viewing figures. None of these two was considered to be a manifestation of PSB crisis. There was no pointing out to a RTV crisis even when three depositions of executive directors and senior managers took place in a six-year period.

\subsubsection{The participants}

The sample consisted of 175 people employed at the regional public service organization (RTV), of which $8.7 \%$ from the top management team, $8.6 \%$ from the Production Department, 6.7\% from the Marketing Department, and 76\% from the Journalism Department. Women made up 51.9\% of the sample and men $48.1 \%$. The respondents were aged $20-64$, both the mean and median being 42. None of the age groups was dominant and the age of 12 respondents was unknown. Length of respondents' work experience in media companies was 1-48 years and median was 18 .

Most participants (56.7\%) had the 4-year bachelor's degree, $18.5 \%$ the threeyear bachelor's (equivalent to associate degree), $7 \%$ the master's degree, and $1.3 \%$ the doctorate degree. The other participants had a four-year $(5 \%)$ or threeyear secondary education (11.5\%).

The independent variable was position in a specific RTV department, with its four levels: top management department, production department, marketing department and journalists department. Dependent variables were participants' assessments of the options in the multiple choice questions. The demographic 
questions provided data on respondents, age, sex, education and length of employment in this media company (employee tenure).

\subsubsection{Measurement instruments}

Regarding the fact that the two earlier attempts to use a similar employee survey were rejected by the RTV management, our survey was designed as a brief exploratory investigation using a questionnaire with only three questions. Each question had several responses to chose from and a space after certain options for respondent's comments, explaining the choice or giving examples. For the question "What influence is of crucial importance for the RTV programming policy?" the following responses were offered: "Existence of programming strategy"; "Research results indicating audiences needs and interests"; "Attracting advertisers"; "Current programme formats"; "Editorial Board's decisions"; "Top management's decisions"; "Personal preferences of the employees". Up to three responses were allowed. The question "Are there direct political influences on your company's programming policy?" had two response options: "Yes" and "No". The third question, "Does your media organisation act in a socially responsible manner?" was clarified by explaining that assessments should be given of economic, legal and ethical aspects of the Company's performance (Carroll 1991) in fulfilling its mission. The response options were: "Acts in a socially responsible manner", "In some aspects partially acts in a socially responsible manner", "Does not act in a socially responsible manner".

The research was conducted in the second part of August 2011. The participants were asked to fill out the questionnaire, following the instructions. The time for filling it out was limited to 10 minutes.

\subsubsection{Statistical data processing}

Respondents' assessments were analyzed relating to particular factors of programme decision making, social responsibility and direct political influence on RTV's programming policy. The frequency of parameters modalities in numbers and percentage was presented in relation to each of the four departments (Top management, Production, Marketing, Journalism).

The SPSS and Statistica programs were used. In addition to description, the results were analysed using Spearman's Rank Correlation, Mann-Whitney U Test, Kruskal-Wallis ANOVA, the Binomial test for a single sample, Kendall Tau coefficient, the Pearson's product-moment correlation, the Two-way ANOVA and the One-way ANOVA. 


\section{Results}

\subsection{General findings}

\subsubsection{Decisive influences on programming policy}

The following two response options to the question "What is a decisive influence on RTV's programming policy?" were chosen most frequently by the respondents from all the four departments: "Current social and political events" (59\%) and "Decisions made at the meetings of the Editorial Board" (49\%). "Top management decisions" and "Attracting advertisers" were the least frequently chosen responses $(7 \%)$.

A series of Mann-Whitney U tests showed no gender-related differences in the frequency of particular response options. Also the Kruskal-Wallis ANOVA series showed no education-related differences.

Regarding the respondents' length of work experience and age, a series of Spearman's Rank Correlation showed that the only statistically significant relationship was with the response "personal priorities of the employees", and it was moderate negative (Spearman $\mathrm{R}=-0,154, \mathrm{p}<0,05$ ). In other words, the older the respondents, the less frequent this response option, though the correlation is low.

The Kruskal-Wallis ANOVA series showed that all the responses were chosen with a similar frequency $(\mathrm{H}(3,173)=9,66 ; \mathrm{p}<0,05)$ except for the response "personal priorities of the employees", which was not chosen by any of the respondents from the Production and Marketing departments. On the contrary, according to the assessments of about one-in-four respondents $(26.52 \%)$ from the Journalism Department and $13.33 \%$ from the top management, the influence of employees' personal priorities on the RTV's programming policy is decisively important.

\subsubsection{Direct political influence}

Negative answers on the question whether there was any direct political influence on the RTV programme policy were given by $51 \%$ of all the respondents, whereas $49 \%$ thought that there was, and some commented their choice.

When using the Kendall Tau coefficient no correlation was found between the responses on this question and respondents' age and length of work experience. The Kruskal-Wallis ANOVA test showed no significant difference between four departments regarding the preference of particular response options. Also no education-related differences were found. The Mann-Whitney U test showed that gender had no significant influence on the respondent's preferences of particular responses on the question about the political influence. 
Generally, the respondents' opinions were uniformly distributed, regardless of sex, department, education or length of work experience, which means that some other factors caused choosing one of the alternatives.

\subsubsection{Acting in a socially responsible manner}

The majority (44\%) of respondents from all the four departments agreed with the assessment option that the media organization they worked for acted in only a "partially responsible manner". A third (33\%) chose the option that it "acts in a socially responsible manner" and around $12 \%$ that it "does not act in a socially responsible way". There was a rather high rate $(11 \%)$ of the item without any response.

Neither age nor length of work experience of those who answered this question correlated significantly with the responses given. The one-way ANOVA showed that education had no influence either.

\subsection{Department specific results}

\subsubsection{Company management}

Some of the answers given by respondents from the top management department were almost unbelievable; 26.7 percent of managers thought that programme strategy was of major influence; another 26.7 percent thought that information on audience's interests and needs were most influential. Most unexpected was the finding that only 27 percent of managers thought that the programme policy was most influenced by "conclusions made by the Editorial board".

The majority of participants (46.7\%) of the top management sample chose the answer that popular programme formats influenced decisively the RTV's programme commitments. "Attracting advertisers" and "Personal preferences" were opted for only $13.3 \%$ and $6.7 \%$ of managers, respectively.

A third of top managers $(33.3 \%)$ in the sample said that there were direct political influences on the programme policy. As regards the RTV's social responsibility, 46.7 percent of managers thought that this PSM ,acted in a socially responsible way"and the other 46.7 percent of answers were that it "acted in partially responsible way". No respondent from this group opted for the answer that the RTV "does not act in a socially responsible way".

\subsubsection{Marketing Department}

Unexpectedly high number of respondents from this department (66.7 percent, as compared to mere 13.3 percent of the managers) agreed with the statement that "attracting advertisers" had major influence on programme policy. Considering the fact that commercials make a rather modest source of the RTV's income, even more in the recent years marked by severe economic recession, this 
high percentage is more an expression of a "high self-esteem" than a realistic "ranking" of particular influences. This conclusion holds since no respondent from this department considered either "top management's decisions" or "personal preferences of the employees" to have decisive influence on programme policy. Following the "attracting advertisers" as the influence most frequently opted for, were "program strategy" (42.0\%) and "research data on interests and needs of the audience" $(41.7 \%)$. Only 16.7 percent of responses were "current programme formats" as well as "decisions made on the meetings of the Editorial Board" that were considered decisively influential on the RTV programme policy.

The majority of respondents in this group thought that the editorial policy was under the political influence $(58.3 \%)$. As for the estimates of social responsibility of the RTV, 50 percent of respondents thought that this broadcaster acts in only partly responsible manner.

Evident differences in responses between managers and the respondents from the Marketing department, especially on "programme strategy" and "audience research" result mostly from the fact that the latter were working with the RTV longer and have directly experienced the media market reality.

\subsubsection{Production Department}

Respondents in this group were less critical towards management: $33.3 \%$ confirmed that the management had decisive influence on programme policy, but even more influence was attributed to "programme strategy" (by $46.7 \%$ respondents). Interests and needs of audiences were regarded as influential by $13.3 \%$, and personal preferences of the employees by $6.7 \%$ of these respondents. 'There are political influences on the editorial policy' said $66.7 \%$ of the respondents from production department.

Much less (53.3\%) agreed that the RTV as a company performed in a "socially responsible manner".

\subsubsection{Department of Journalism}

Journalists' responses showed that "research data on interests and needs of the audience" and "current programme formats" were considered of most decisive influence on programme policy $(38.3 \%$ and $31.6 \%$ positive answers, respectively), followed by "programme strategy" $(27.8 \%)$ and "decisions made on the meetings of the Editorial Board" (22.6\%). Strangely enough, RTV has not yet published or in any other way explained to those who pay the licence fee its overall strategy in fulfilling its public service mission. Thus, relatively high importance of programme strategy as perceived by $27.8 \%$ of journalists in our research can only be understood as referring to immanent strategic value of decisions on programming commitments and priorities made by the Editorial Board. This is even suggested by the fact that only $10.5 \%$ of journalists considered top 
management's decisions as decisively influential on programming commitments. Around $8 \%$ of journalists thought that "attracting advertisers" was so influential, and merely $4.5 \%$ opted for "personal priorities of the employees".

It was only this group of respondents that direct denials of 'the RTV's socially responsible acting' came from - in $15.8 \%$ of answers, and furthermore $43.6 \%$ of journalists thought that RTV acts in only a "partially responsible manner".

Direct political influence(s) on this public broadcaster were confirmed in $48.1 \%$ of journalists' answers.

\section{Conclusions}

It is getting harder and harder for the public service media in Serbia to survive in their present form. Since 2008 the crisis they have faced has become harder to cope with: the income from the license fee has severely decreased; the competition with private domestic broadcasters and the increasing number of cable and satellite channels has saturated their target market; the political party elites persistently interfere in PBS performance. The characteristics of innovative processes in electronic media and increasingly shortened life cycle of media products make the challenges even more difficult to address.

Institutional legitimacy of the regional PSB Radio Televizija Vojvodina (RTV) has been the subject of debates since the concept of public service broadcasting was introduced by the 2002 Broadcasting Law. Since the actual introduction of the concept of PSB in 2005/6 until early 2012 no major changes have been made in services delivered and the way the RTV operates (the only novelty is gradual introduction of basic online services). However, there were three depositions of executive directors and senior managers between 2005 and 2011. Thus, due to the RTV deep institutional roots and proximity to centres of political power the crisis that emerged with the introduction of foreign and domestic private TV channels in 1990s has never been recognized as a crisis nor dealt with accordingly. Our analysis indicates that some aspects of the crisis (Channel One viewing figures and unsatisfactory accessibility in the very province of Vojvodina, for example) should be considered as a result or at least being partially caused by its management's insufficient competence and responsibility. The survey on the sample of the RTV staff employed in four departments revealed the opinions and attitudes that supported the following conclusions:

- The RTV does not have a clearly defined strategy as the executive directors' operationalized vision of the RTV's mission in rapidly changing economic and social circumstances;

- The influence of the senior management on programme policy is not transparent; however, it is perceived by the staff as being more guided by political than professional discipline and responsibility; 
- Current policy, namely power relationships among parliamentary parties elites has a direct influence on the overall performance of this regional PSB;

- Social responsibility of the RTV is more a residue of the socialist praxis of relationship between cultural-informative institutions and public than a distinctive praxis projected and supported by legitimistic and legalistic criteria. Hence it appears to be exhausted in simple media campaigns and has not yet become part of this company's organizational culture.

The 1970s and the first decade of the 21 st century were marked by some undoubtedly high achievements of the major broadcasting organizations in Serbia regarding quality of content delivered and substantial editorial independency. Such a history makes it easier to believe that the optimistic scenarios for the future of Serbian public service media and the RTV itself are still possible. However, for any optimistic scenario the following would be necessary:

- Transparency of the RTV operation, accessibility of relevant information on this PSB's organisational structure, annual plans and reports (by the end of 2011 only the names and office phone numbers of managers and editors were available on the RTV website);

- Not only normative acceptance, but actual applying of the principle that communication provided by the public broadcaster is a public good. The tough times require strategic managerial decisions based on professional responsibility and leadership competence. The praxis needs permanent competence through defining short to medium-term programming commitments and priorities within regular business plans for the mandate period;

- Introduction of the RTV performance auditing. However, such a novelty would require massive political changes on national level. Perhaps political orientation toward EU membership will help create such legal and political environment that requires consistent discipline and responsibility in managing public media companies;

- The quality of program content in terms of its cognitive, emotional and production values should be a primary objective regarding the leading role of electronic media in cultural sustainability. In times of extreme financial crisis creative staff can prove to be primary assets if management enhances mutual trust;

- The top management team should consistently encourage the culture of readiness for change and optimised risk taking. For senior managers themselves this should mean a necessity of difficult decisions about reducing the non-productive, high salary positions to a justifiable number, as well as earning trust by supporting and defending editorial independence. 
Our approach to the crisis of public service media was focused on examining one particular aspect of crisis - the role that management has or might have in addressing it, as well as in deepening it. The case of the RTV as the regional PSB in Serbia illustrates a specific position of these companies in low income transitional European countries facing severe recession. It is of great importance that leadership competence of regional public broadcaster's top management combines three managerial qualities: professional integrity in coping with political pressures; their recognition of decisive importance of creative/innovative potential of people who create the programme, and their belief that the PSB organisations should defend the standards of high-quality journalism, as one of the preconditions for contributing to public good.

\section{References}

ANEM - The Association of Independent Electronic Media (2011): Država i dalje nespremna da se povuče iz medija [The Government is still not ready to withdraw from the media]. URL: http://www.vesti.rs/Vesti/ANEM-Drzava-i-dalje-nespremna-da-se-po vuce-iz-medija.html (accessed 9 September 2011).

Bajomi-Lazar P (2002): Public Service Television in East Central Europe: A Comparative Study. Paper prepared for the International Federation of Journalists, Budapest.

BBC Trust (2010, March): BBC Strategy Review. London: BBC Trust.

Blumler, J.G./Gurevitch, M. (1995): The crisis of public communication. London and New York: Routlege.

Brevini, B. (2010): Towards PSB 2.0? Applying the PSB ethos to online media in Europe: A comparative study of PSBs' internet policies in Spain, Italy and Britain, in: European Journal of Communication, 25, 4, 348-365.

Car, V. (2007): Konvergirani javni medijski servis [Converged public media service], in: Politička misao, 44, 2, 113-127.

Carroll, A.B. (1991): The Pyramid of Corporate Social Responsibility: Toward the Moral Management of Organizational Stakeholders, in: Business Horizons, 34, 4, 39-48.

Collins, R./Finn, A./McFadyen, S./Hoskins, C. (2001): Public Service Broadcasting Beyond 2000: Is There a Future for Public Service Broadcasting?, in: Canadian Journal of Communication, 26, 1, 3-15.

DiMaggio, P.J./Powell, W.W. (1983): The Iron Cage Revisited: Institutional Isomorphism and Collective Rationality in Organizational Fields, in: American Sociological Review, 48, 2, 147-160.

Hallin, D.S./Mancini, P. (2004): Comparing Media Systems - Three Models of Media and Politics. Cambridge: Cambridge University Press.

Hallin, D.C./Stylianos, P. (2002): Political Clientelism and the Media: Southern Europe and Latin America in Comparative Perspective, in: Media, Culture \& Society, 24, 2, 184 185.

Hayek, F. (1945): The use of knowledge in society, in: American Economic Review, 35, 4, 519-530. 
Hermida, A./Ash, A. (2010): Wikifying the CBC: Reimagining the remit of public service media. URL: http://online.journalism.utexas.edu/2010/papers/HermidaAsh10.pdf (accessed 31 October 2011).

Jakubowicz, K. (2008): Participation and Partnership: A Copernican Revolution to ReEngineer Public Service Media for the 21st Century. Keynote Presentation prepared for the RIPE@2008 conference "Public Service Media in the 21st Century: Participation, Partnership and Media Development”, Mainz, Germany, October 9-11.

Jakubowicz, K. (2006): Public service broadcasting: a new beginning, or the beginning of the end? Presentation for the RIPE@2006 Conference: "Public Service Broadcasting in the Multimedia Environment: Programmes and Platforms".

Jakubowicz, K./Sükösd, M. (2008): Twelve Concepts Regarding Media System Evolution and Democration in Pos-Comunist Societas, in: Jakubowicz, K. and Sükösd (ed.): Finding the Right Place on the Map Central and Eastern European Media Change in a Global Perspective. Chicago, IL: University of Chicago Press, 9-40.

Kivikuru, U. (2006): Top-Down or Bottom-up. Radio in the Service of Democracy: Experiences from South Africa and Namibia, in: The International Communication Gazette, $68,1,5-31$.

Koelble, T.A. (1995): The New Institutionalism in Political Science and Sociology, in: Comparative Politics, 27, 2, 231-243.

Levy, D.A. (1999): Europe's Digital Revolution. Broadcasting regulation, the EU and the nation state. London: Routledge.

Lowe, G.F. (2007): The role of public service media for widening individual participation in European democracy. Report prepared for the Council of Europe's Group of Specialists on Public Service Media in the Information Society (MC-S-PSM). Strasbourg: Media Division, Directorate General of Human Rights and Legal Affairs, Council of Europe.

Lowe, G.F./Bardoel, J. (2007): From Public Service Broadcasting to Publice Service Media. RIPE@2007. Nordicom, Gőteborg, Sweden.

McQuail, D. (2003): Public Service Broadcasting: Both Free and Accountable, in: The Public/Javnost, 10, 3, 13-23.

Milivojević, S. (2006): Televizija u tranziciji: Od državne kontrole do divljeg tržišta [From state control to the wild market], in: Mihajlović, S. (ed.): Pet godina tranzicije u Srbiji II [Five Years of Transition in Serbia II]. Belgrade: Socijaldemokratski klub; Fondacija Friedrich Ebert, 272-286.

Moe, H./Syvertsen, T. (2007): Media Institutions as a Research Field. Three Phases of Norwegian Broadcasting Research, in: Nordicom Review, 28, 149-167.

Nissen, C.S. (2006a): No public service without both Public and Service - Content provision between the Scylla of populism and the Charybdis of elitism, in: Nissen, C.S. (ed.): Making a Difference / Public Service Broadcasting in the European Media Landscape. John Libbey \& Co Ltd, 65-82.

Nissen, C.S. (2006b): Public service media in the information society. Report prepared for the Council of Europe's Group of Specialists on Public Service Broadcasting in the Information Society (MC-S-PSB). 
North, D. (1991): Institutions, Institutional Change and Economic Performance. Cambridge: Cambridge University Press.

Oliver, Ch. (1991): Strategic Responses to Institutional Processes, in: Academy of Management Review, 16, 1, 145-179.

Owen, J. (1996): Crisis or renewal: the origins, evolution and future of public service broadcasting 1922 to 1996 . PhD thesis, University of Westminster, School of Media, Arts and Design.

Picard, R.G. (2003): Assessment of Public Service Broadcasting: Economic and Managerial Performance Criteria, in: The Public/Javnost, 10, 3, 29-44.

Ratković Njegovan, B./Šiđanin, I. (2012): Management Strategies in the Media in the Framework of Economic and Financial Crisis. XVII International Scientific Symposium, SM2012 "Strategic management and Decision Support Systems in Strategic Management". Book of Abstracts, Subotica: Faculty of Economics, 92-93.

Simon, H.A. (1957): Models of Man, Social and Rational: Mathematical Essays on Rational Human Behavior in a Social Setting. New York: John Wiley and Sons.

Sparrow, B.H. (1999): Uncertain guardians: The news media as a political institution. Baltimore: Johns Hopkins University Press.

Splichal, S. (2001): Imitative revolutions. Changes in the Media and Journalism in EastCentral Europe, in: The Public/Javnost, 88, 4, 31-58.

Steemers, J. (1999): Between Culture and Commerce: The Problem of Redefining Public Service Broadcasting for the Digital Age, in: Convergence, 5, 3, 44-67.

Suter, T. (2005): Offcom review of public service television broadcasting. Presented at the meeting on the European Platform of Regulatory Authorities, Sarajevo.

Williamson, O.E. (1991): Comparative Economic Organization: The Analysis of Discrete Structural Alternatives, in: Administrative Science Quarterly, 36, 2, 269-296.

\section{Sources}

Amsterdam Protocol (1997): Protocol on the system of public broadcasting in the Member States. O. J. 10. 11. 1997 C 340/109. URL: http://eur-lex.europa.eu/en/treaties/dat/ 11997D/htm/11997D.html\#0109010012 (accessed 16 March 2013).

EBU/GEAR (2010, May): Country Reports: Recent Developments in Media, Broadcasting \& Audience Research.

EBU Strategic Information Service (2009, November): Broadcasters and the Internet. URL: http://s3.amazonaws.com/zanran_storage/www.ebu.ch/ContentPages/58291039.pdf (accessed 19 March 2013).

EBU - UER (2011): Annual Report 2011.

RBA - Republic Broadcasting Agency of Serbia (2011): Godišnji izveštaj, 2010. Program na srpskom jeziku - RTV 1 [Annual Report, 2010. Programme in Serbian - RTV 1].

Statistical Office of the Republic of Serbia (2011) Census of Population, Households and Dwellings in the Republic of Serbia. 
Strategic Marketing Research (2007): Istraživanje: "Novinari i novinarstvo u očima građana i novinara Srbije" [Research: "Journalist and journalism in the eyes of citizens and journalists of Serbia"]. URL: http://www.anem.rs/sr/medijskaScena/istrazivanja/story/ .html (accessed 12 October 2010). 